LUBLIN STUDIES IN MODERN LANGUAGES AND

LITERATURE 39 (2), 2015, HTTP://WWW.LSMLL.UMCS.LUBLIN.PL

\author{
Salameh Fleih Obeiah \\ Ministry of Education \\ Mafraq, Jordan \\ Ruba Fahmi Bataineh \\ Yarmouk University \\ Irbid, Jordan
}

\title{
Does Scaffolding-Based Instruction Improve Writing Performance? The Case of Jordanian EFL Learners
}

\begin{abstract}
The present study examines the potential effect of scaffolding instruction on Jordanian EFL tenth-grade students' overall writing performance and their performance on the sub-skills of focus, development, organization, conventions and word choice. The study follows a quasi-experimental experimental/control group, pre-/post test design. In the experimental group, 20 female tenth-grade students from the North-Eastern Badia Directorate of Education (Jordan) were taught to generate ideas, structure, draft, and edit their essays using agency scaffolding and the scaffolding principles of contextual support, continuity, intersubjectivity, flow, contingency and handover, within the Zone of Proximal Development. Another group of 28 students was instructed conventionally per the guidelines outlined in the Teacher's Book. After the treatment, descriptive statistics and ANCOVA were used to analyze the students' scores on the pre-test and the post test. The results showed that the scaffolding instruction group outperformed the control group (at $\alpha \leq 0.05$ ) in their overall writing performance and in their performance on all writing sub-skills except the sub-skill of development.
\end{abstract}


Keywords: Jordan; scaffolding; writing performance; Zone of proximal development

1. Introduction and background

Writing is reportedly neglected not only in Jordan but worldwide by teachers and students alike, as only small portion of the class-time is given to develop this skill. Jordanian foreign language learners suffer from weakness in writing despite massive efforts, by both teacher educators and the Ministry of Education, to overcome it. In Jordan, as in several other parts of the world where English is taught as a foreign language (EFL), teachers tend to concentrate more on structure than writing (e.g., Al-Omari, 2004; Al-Quran, 2002; Al-Sharah, 1988). To make matters worse, even when they do focus on writing, teachers give priority to mechanics over process (Abu-Jaleel, 2001; Bani Younis, 1997; Hawari, 1996).

In the Vygotskian sociocultural theory (1987), unlike their traditional role of passive recipients of knowledge, learners are considered active agents and members of the target language community (Mitchell \& Myles, 2004). Building on Vygotsky's work, Lantolf (2000) put forth sociocultural second language acquisition (SLA), a paradigm in which the teacher, or any other more knowledgeable other (MKO), activates and makes use of the learner's potential by scaffolding him/her within his/her zone of proximal development (ZPD).

Educational experts (e.g., Clark \& Graves, 2005; Harrison, 2004) see ZPD as the backbone of Vygotsky's sociocultural theory. In Vygotsky's (1978:86) own words, ZPD is "the distance between actual developmental levels as determined by independent problemsolving and the level of potential development as determined through problem-solving under adult guidance or in collaboration with more capable peers". Scaffolding has evolved as a metaphor for the interaction between an expert and a novice learner engaged in a problem- solving task, which is beyond the learner's capacity, thus 
permitting him/her to concentrate upon and complete only those elements that are within his/her range of competence (Wood, 1998).

Hannafin, Land, and Oliver (1999) suggested four kinds of scaffolding: (1) conceptual scaffolding which means providing guidance on what to consider, (2) metacognitive scaffolding which demands guidance on how to think about the problem under study, (3) procedural scaffolding which refers to guidance on how to use resources and tools, and (4) strategic scaffolding which is used to give guidance on ways to solve the problem. On the other hand, Holton and Clarke (2006) proposed two types of scaffolding: domain and agency. Domain scaffolding is further divided into conceptual and heuristic. Conceptual scaffolding is concerned with the development of concepts whereas heuristic scaffolding is concerned with finding approaches to solving a problem. Agency scaffolding, which is used in this study, consists of three types: expert, reciprocal and self-scaffolding. Expert scaffolding refers to the scaffolding offered by an expert; reciprocal scaffolding refers to an activity where students work in groups; and self-scaffolding indicates a situation when someone is scaffolding oneself.

In the field of language learning, Van Lier (1996) addressed six features of scaffolding, which were all incorporated in this research:

1. continuity or repeated occurrences over time with interconnected variations,

2. contextual support manifested in a safe but challenging environment in which errors are expected and accepted as part of the learning process,

3. intersubjectivity or the mutual engagement and support between an expert and a novice (two minds working as one),

4. contingency manifested in providing support (by adding, modifying, deleting or repeating) depending on the learners' reactions,

5. handover/takeover or increasing the learner's role as his/her skills and confidence increase, and

6. flow manifested in natural, rather than forced, communication between participants. 
2. Problem and purpose of the study

Learning to write well in the EFL classroom may be difficult for most learners, as they have to encounter a set of challenges, most important among which is grasping grammatical, lexical, syntactic, semantic and writing mechanics (e.g., Al-Gomoul, 2011; Al-Jarf, 2007; Hyland, 2003; Soles, 2005). In the Jordanian EFL classroom, writing instruction is essentially traditional, which has been documented as the major cause for student weakness (e.g., Al Omari, 2004; AlQuran, 2002; Al-Sharah, 1988). As scaffolding instruction has been reported to allow prospective gains for EFL students (e.g., Bodrova, 1998; Eickholdt, 2004; Schwieter, 2010), these researchers examine its potential effectiveness, possibly for the first time, in the Jordanian EFL context.

Thus, the study investigates the potential effect of scaffolding instruction on Jordanian EFL tenth-grade students' overall writing performance and their performance on the writing sub-skills of focus, development, organization, conventions, and word choice.

3. Questions and hypotheses of the study

The study attempts to answer the following questions:

1. To what extent does scaffolding instruction affect Jordanian EFL students' writing performance?

2. To what extent does scaffolding instruction affect Jordanian EFL students' writing performance on the sub-skills of focus, development, organization, conventions and word choice?

To achieve the purpose of the study, these questions are expressed in the following statistically testable hypotheses:

1. Ho1. Scaffolding instruction has no significant effect (at $\alpha \leq$ 0.05 ) on Jordanian EFL tenth-grade students' overall writing performance.

2. Ho2. Scaffolding instruction has no significant effect (at $\alpha \leq$ 0.05) on Jordanian EFL tenth-grade students' writing performance on the sub-skills of focus, development, organization, conventions and word choice. 
4. Significance of the study

An extensive review of the literature on scaffolding instruction has only produced research conducted abroad (e.g., Lutz, Guthrie, \& Davis, 2006; Schwieter, 2010; Baradaran \& Sarfarazi, 2011). No research on the use of scaffolding instruction in the Jordanian classroom in general and the EFL classroom in particular has been found. Thus, this study may very well be the first to examine scaffolding instruction and its potential gains in the Jordanian EFL writing classroom.

In addition, this study is meant to inform Jordanian EFL teachers, who are seeking alternative instructional strategies for developing EFL students' writing proficiency. The findings reported in this study may also inform curriculum designers and policy-makers about the potential utility of scaffolding for teaching writing to Jordanian EFL students.

\section{Previous literature}

As noted earlier, the review has revealed a dearth of local (and Arab region) studies on the effect of scaffolding instruction in the foreign language classroom. To the best of the researchers' knowledge, this study is the first in Jordan to investigate the effect of scaffolding instruction on improving EFL students' writing performance.

Thus, this review is limited to foreign research, which seems to provide empirical evidence that scaffolding instruction does significantly contribute to the improvement of EFL students' writing performance. Bodrova (1998) claimed that scaffolding supports children emergent writing and allows them to transition from assisted to independent performance within the ZPD. Similarly, Eickholdt (2004) suggested that scaffolding potentially supports the development of young writers.

Schwieter (2010) also reported supporting evidence that scaffolding writing techniques and feedback effectively develops writing skills when contextualized through a writing workshop involving the creation of a professional magazine designed for an authentic audience. Similarly, both Baradaran and Sarfarazi (2011) 
Does Scaffolding-Based Instruction Improve Writing Performance? 111

and Hayati and Ziyaeimehr (2011) reported significant gains in Iranian EFL university students' writing performance as the result of scaffolding instruction.

6. Methods and procedure

The study uses the quasi-experimental design on two intact tenthgrade sections, randomly divided into an experimental group and a control group. The study has three variables: the independent variable of scaffolding instruction and the two dependent variables of overall writing performance and writing performance in the sub-skills of focus, development, organization, conventions and word choice.

The participants of this study are 48 female Jordanian EFL tenthgrade students purposefully chosen from the public schools in the North-Eastern Badia Directorate of Education, Jordan. The experimental group $(n=20)$ was taught through scaffolding, while the control group $(n=28)$ was taught conventionally per the guidelines of the Teacher's Book.

To achieve the purpose of the study, the researchers made use of the following instruments:

1. A pre-test in which the participants were asked to write a 75100-word one/two-paragraph essay about trees,

2. a post test in which the participants were asked to write a 75100-word one/two-paragraph essay about rainforests, and

3. an Analytic Scoring Rubric adapted from Wang and Laio's (2008) Scoring Rubric to assess the sub-skills of focus, development, organization, conventions and word choice.

The validity of the pre-test, post test and rubric was established by an expert jury of Jordanian university professors in education, measurement and evaluation and curriculum and instruction. The jury's recommendations for the tests and the rubric were all taken into account and reflected in the final versions of the three instruments.

To establish the reliability of the pre-test and the post test, they were both administered to two groups of tenth-grade students from the North-Eastern Badia Directorate of Education, which were excluded from the sample of the study. Three weeks later, the same students sat 
for the same tests. The reliability coefficients amounted to 0.96 for the pre-test and 0.89 for the post test, which are considered appropriate for the purposes of this research.

The participants' essays were assessed by two experienced EFL instructors: the second researcher, who is an EFL supervisor, and an instructor of English language and literature at a Jordanian university, using an adapted version of Wang and Laio's (2008) scoring rubric which consists of the five sub-skills of focus, development, organization, conventions and word choice. The researchers have trained the other rater on using the scoring rubric before entrusting him with scoring the students' responses.

To establish inter-rater reliability, the two raters scored 15 students' responses on the pre-test using the same rubric. Then, the reliability coefficient was calculated using Holsti formula. The interrater reliability was found to be 0.92 , which is appropriate for the purposes of this research.

To establish intra-rater reliability for each rater, the two raters were each asked to evaluate the same sample of the pre-test responses using the same scoring rubric. The intra-rater reliability was found to be 0.89 for the first rater and 0.86 for the second rater, which are both appropriate for the purposes of this research.

The data collection was done per the following procedures:

1. The school respondents and the principal's consent to carry out the study was obtained.

2. Two sections from a public school for girls were purposefully chosen to comprise the sample of this study.

3. The participants of the experimental and the control groups were pre-tested (75-100-word-eassay about trees).

4. Lesson plans were designed based on Holton and Clarke's (2006) agency scaffolding and Van Lier's (1996) scaffolding principles to teach the experimental group. The instructor/ second researcher scaffolded the students' writing, using the following principles:

a. Contextual Support. At this stage, the instructor sought to establish an understanding of the purpose of the text, the 
roles and relationships of its potential users and the social activity in which it is used. Thus, the need for audience awareness was emphasized; students were constantly made aware that what they write was intended to be read, not only assessed, by their group members, other students in the class, and the instructor. However, for them to own up for their essays, they were encouraged to think that they themselves were the first (and last) readers of these essays and, thus, to be reflective about their own writing.

b. Continuity. At this stage, the instructor put forth a schedule for posting assignments. For example, students were given deadlines for essay submission and directions regarding the manner of submission (with comments, questions or points for further discussion). In addition to being assessed by the instructor, all postings were read by other fellow students. As the students became more comfortable within the routine, additional elements were added or amended. For example, as students got used to providing peer feedback, they were encouraged to construct similar texts before another text type was introduced. The extent and type of feedback was varied according to the students' emergent skills and the increased range and difficulty of the target text.

c. Intersubjectivity. Here, the students were asked to write collaboratively on a topic relevant to their learning, per general outlines discussed in the class. In the following lesson, the conceptual content presented in the previous lesson was reinforced and extended, and the group members engaged in exploratory talk, building on each other's ideas to work towards a common goal. Before they left the class, they were encouraged to agree on what was to be done in the next phase of the assignment. Individual students then drafted and posted their essays for withingroup assessment, thus encouraging intersubjective 
collaboration. The instructor's responsibility was to create a conducive environment for students' collaboration.

d. Flow. At this stage, students were allowed opportunities to meet informally to discuss issues arising from their work. The large number of postings, whose content and procedural issues were negotiated by students and instructor, constituted evidence of natural flow in a free give-and-take written discourse.

e. Contingency. Here, the instructor scaffolded the students' learning by constantly monitoring their essay drafts. He responded and provided support, raising or lowering the scaffold on a needs basis. Contingent scaffolding was also provided in the face-to-face sessions to provide extra assistance and practice in the skills taught during lessons, to answer questions, suggest ideas for strategies, maintain focus and motivation, and deal with emergent problems. Elements of writing were added, deleted or adapted for individuals, groups, or the whole class according to their development through the ZPD.

f. Handover. Here, the co-constructed drafts were edited by the instructor to the students' satisfaction, after which they were allowed to make last-minute modifications to their essays before submission. Students, individuals or groups, met the instructor in separate mini-conferences to discuss their work. In most cases, the students have written at a higher level of proficiency, which marked the conclusion of one ZPD and the start of another.

Furthermore, the three types of scaffolding were implemented as follows:

a. In expert scaffolding, the instructor/second researcher scaffolded the composition process through different types of actions, such as providing information, encouragement, suggestions, awareness, remedies and reminders.

b. In reciprocal scaffolding, students worked collaboratively to construct knowledge (Holton \& Clarke, 2006). Unlike 
expert scaffolding, reciprocal scaffolding contains a twoway discourse between those engaged in the discourse. The instructor/second researcher provided students with reciprocal scaffolding through five types of action: (1) providing information, (2) making suggestions, (3) reflections, (4) confirmations, and (5) explanations.

c. Finally, in self-scaffolding, students constructed knowledge within themselves. They compared incoming information and adjusted their current knowledge structures in light of the new information (Holton \& Clarke, 2006). Self-scaffolding was provided through (1) providing information, (2) providing confirmations, and (3) raising awareness.

On the other hand, the control group was instructed conventionally per the Teacher's Book. The instructor/second researcher followed the procedures outlined in the Teacher's Book of the textbook, Action Pack 10, as follows:

a. He taught students how to declare their statements in the introduction and how to support their beliefs in both the introduction and the conclusion.

b. They learned how to state the purpose of the essay. The instructor/researcher also taught the students how to generate ideas, structure, and draft and edit their essays.

c. They wrote individually and did not engage in any pair/group in the classroom.

Statistical analyses were performed using Pearson's Correlation Coefficient for the test-retest reliability of the pre- and post tests, Holisti Formula for the inter- and intra-rater reliability, and descriptive statistics to compare means and standard deviations of the experimental and control groups. ANCOVA was also used to control the differences between the groups before the treatment and to detect potentially significant differences (at $\alpha \leq 0.05$ ) between the experimental and control groups after the treatment. 
7. Findings of the study

Each research question is addressed by testing its relevant hypothesis, drawing on information from the relevant sources of data obtained in the course of the study.

To test the first hypothesis, scaffolding instruction has no significant effect on Jordanian tenth-grade EFL students' overall writing performance (at á $\leq 0.05$ ), means and standard deviations of the students' scores on the pre-test and the post test were calculated, along with adjusted mean scores and the standard errors of the post test scores based on the differences between the two levels of instructional delivery, scaffolding instruction and the conventional method, as shown in Table 1.

Table 1. Means and Standard Deviations of Students' Overall Writing Performance on the Pre-test and the Post Test by Mode of Instructional Delivery.

\begin{tabular}{|c|c|c|c|c|c|c|}
\hline \multirow[b]{2}{*}{ Group } & \multicolumn{2}{|c|}{ Pre-Test } & \multicolumn{2}{|c|}{ Post Test } & \multirow{2}{*}{$\begin{array}{l}\text { Adjusted } \\
\text { Mean }\end{array}$} & \multirow{2}{*}{$\begin{array}{l}\text { Standard } \\
\text { Error }\end{array}$} \\
\hline & Mean & $\begin{array}{l}\text { Standard } \\
\text { Deviation }\end{array}$ & Mean & $\begin{array}{l}\text { Standard } \\
\text { Deviation }\end{array}$ & & \\
\hline Control & 6.46 & 1.91 & 8.03 & 2.00 & 5.61 & 0.60 \\
\hline Experimental & 2.35 & 2.56 & 7.20 & 5.94 & 10.59 & 0.74 \\
\hline
\end{tabular}

Table 1 shows that there are differences between the two groups' overall writing performance in favor of the experimental group. To determine if this difference is statistically significant, ANCOVA is used, as shown in Table 2, below. 
Does Scaffolding-Based Instruction Improve Writing Performance? 117

Table 2. ANCOVA of the Students' Overall Performance.

\begin{tabular}{|c|c|c|c|c|c|c|}
\hline Source & $\begin{array}{c}\text { Sum of } \\
\text { Squares }\end{array}$ & Df & $\begin{array}{c}\text { Mean } \\
\text { Squares }\end{array}$ & F & Sig. & $\begin{array}{c}\text { Partial Eta } \\
\text { Squared }\end{array}$ \\
\hline $\begin{array}{c}\text { Overall } \\
\text { pre }\end{array}$ & 447.13 & 1 & 447.13 & 60.41 & $0.000^{*}$ & \\
\hline Way & 153.82 & 1 & 153.82 & 20.78 & $0.000^{*}$ & 0.31 \\
\hline Error & 333.02 & 45 & 7.40 & & & \\
\hline $\begin{array}{c}\text { Corrected } \\
\text { Total }\end{array}$ & 788.31 & 47 & & & & \\
\hline
\end{tabular}

$\mathrm{n}=48 \quad *$ Significant (at $\alpha \leq 0.05$ )

Table 2 shows a statistically significant difference on students' overall writing performance on the post test $(\mathrm{F}=20.78, \mathrm{df}=47,1 \mathrm{P}=$ 0.000). Therefore, the first hypothesis, scaffolding instruction has no significant effect on Jordanian tenth-grade EFL students' overall writing performance (at $\alpha \leq 0.05$ ), is rejected.

To test the second hypothesis, scaffolding instruction has no significant effect on Jordanian tenth-grade EFL students' writing performance on the sub-skills of focus, development, organization, conventions and word choice (at $\alpha \leq 0.05$ ), means and standard deviations for the students' scores on the pre-test and the post test on the writing sub-skills were calculated, along with adjusted mean scores and the standard errors of the post test scores based on the difference between the scaffolding instruction and the conventional method, as shown in Table 3. 
Table 3. Means and Standard Deviations of Students' Performance on the Writing Sub-Skills.

\begin{tabular}{|c|c|c|c|c|c|c|c|c|}
\hline \multirow[b]{2}{*}{ Group } & \multirow[b]{2}{*}{ Skills } & \multirow[b]{2}{*}{$\mathbf{n}$} & \multicolumn{2}{|c|}{ Pre-Test } & \multicolumn{2}{|l|}{ Post test } & \multirow[b]{2}{*}{$\begin{array}{l}\text { Adjusted } \\
\text { Mean }\end{array}$} & \multirow[b]{2}{*}{$\begin{array}{l}\text { Standard } \\
\text { Error }\end{array}$} \\
\hline & & & Mean & $\begin{array}{l}\text { Standard } \\
\text { Deviation }\end{array}$ & Mean & $\begin{array}{l}\text { Standard } \\
\text { Deviation }\end{array}$ & & \\
\hline \multirow{5}{*}{ Control } & Focus & \multirow{5}{*}{28} & 1.39 & 0.68 & 1.92 & 0.60 & 1.70 & 0.13 \\
\hline & Development & & 1.03 & 0.42 & 1.50 & 0.63 & 1.23 & 0.16 \\
\hline & Organization & & 1.10 & 0.41 & 1.50 & 0.57 & 1.11 & 0.18 \\
\hline & Conventions & & 1.03 & 0.33 & 1.21 & 0.41 & 0.78 & 0.13 \\
\hline & Word Choice & & 1.89 & 0.41 & 1.89 & 0.31 & 1.33 & 0.14 \\
\hline \multirow{5}{*}{ Experimental } & Focus & \multirow{5}{*}{20} & 0.85 & 1.03 & 1.85 & 1.53 & 2.16 & 0.15 \\
\hline & Development & & 0.30 & 0.57 & 1.30 & 1.17 & 1.67 & 0.20 \\
\hline & Organization & & 0.20 & 0.41 & 1.35 & 1.18 & 1.89 & 0.22 \\
\hline & Conventions & & 0.25 & 0.44 & 1.20 & 1.10 & 1.80 & 0.17 \\
\hline & Word Choice & & 0.75 & 0.55 & 1.50 & 1.19 & 2.27 & 0.17 \\
\hline
\end{tabular}

Table 3 shows differences in performance on the writing sub-skills between the experimental and control groups in favor of the experimental group. To determine if this difference is statistically significant, ANCOVA is used, as shown in Table 4, below.

Table 4. ANCOVA of the Students' Performance on the Writing Sub-Skills by Mode of Instructional Delivery.

\begin{tabular}{|c|l|r|r|r|r|r|r|}
\hline \multirow{2}{*}{ Skills } & Source & $\begin{array}{r}\text { Sum of } \\
\text { Squares }\end{array}$ & Df & $\begin{array}{c}\text { Mean } \\
\text { Squares }\end{array}$ & F & Sig. & $\begin{array}{c}\text { Partial } \\
\text { Eta } \\
\text { Squared }\end{array}$ \\
\hline \multirow{3}{*}{ Focus } & Focus pre & 33.44 & 1 & 33.44 & 71.78 & $0.000 *$ & \\
\cline { 2 - 8 } & Way & 2.29 & 1 & 2.29 & 4.92 & $0.03 *$ & 0.099 \\
\cline { 2 - 8 } & Error & 20.96 & 45 & 0.46 & & & \\
\cline { 2 - 9 } & $\begin{array}{l}\text { Corrected } \\
\text { Total }\end{array}$ & 54.47 & 47 & & & & \\
\hline Development & $\begin{array}{l}\text { Development } \\
\text { pre }\end{array}$ & 8.42 & 1 & 8.42 & 13.18 & $0.001 *$ & \\
\cline { 2 - 9 } & Way & 1.43 & 1 & 1.43 & 2.24 & 0.14 & 0.048 \\
\hline
\end{tabular}


Does Scaffolding-Based Instruction Improve Writing Performance? 119

\begin{tabular}{|c|c|c|c|c|c|c|c|}
\hline Skills & Source & $\begin{array}{c}\text { Sum of } \\
\text { Squares }\end{array}$ & Df & $\begin{array}{c}\text { Mean } \\
\text { Squares }\end{array}$ & $\mathbf{F}$ & Sig. & $\begin{array}{c}\text { Partial } \\
\text { Eta } \\
\text { Squared }\end{array}$ \\
\hline & Error & 28.77 & 45 & 0.63 & & & \\
\hline & $\begin{array}{l}\text { Corrected } \\
\text { Total }\end{array}$ & 37.66 & 47 & & & & \\
\hline \multirow{4}{*}{ Organization } & $\begin{array}{l}\text { Organization } \\
\text { pre }\end{array}$ & 8.32 & 1 & 8.32 & 13.76 & $0.001 *$ & \\
\hline & Way & 3.22 & 1 & 3.22 & 5.32 & $0.026 *$ & 0.106 \\
\hline & Error & 27.22 & 45 & 0.60 & & & \\
\hline & \begin{tabular}{l|} 
Corrected \\
Total \\
\end{tabular} & 35.81 & 47 & & & & \\
\hline \multirow{4}{*}{ Conventions } & $\begin{array}{l}\text { Conventions } \\
\text { pre }\end{array}$ & 11.49 & 1 & 11.49 & 31.51 & $0.000 *$ & \\
\hline & Way & 5.78 & 1 & 5.78 & 15.85 & $0.000 *$ & 0.26 \\
\hline & Error & 16.41 & 45 & 0.36 & & & \\
\hline & \begin{tabular}{l|} 
Corrected \\
Total
\end{tabular} & 27.91 & 47 & & & & \\
\hline \multirow{4}{*}{ Word Choice } & $\begin{array}{l}\text { Word Choice } \\
\text { pre }\end{array}$ & 14.22 & 1 & 14.22 & 41.40 & $0.000 *$ & \\
\hline & Way & 4.20 & 1 & 4.20 & 12.24 & 0.001 * & 0.21 \\
\hline & Error & 15.45 & 45 & 0.34 & & & \\
\hline & $\begin{array}{l}\text { Corrected } \\
\text { Total }\end{array}$ & 31.47 & 47 & & & & \\
\hline
\end{tabular}

$n=48$

* Significant (at $\alpha \leq 0.05$ )

Table 4 shows a statistically significant difference (at $\alpha \leq 0.05$ ) in students' performance on the writing sub-skills of conventions, word choice, organization and focus, respectively, and no statistically significant difference in the sub-skill of development $(\mathrm{F}=2.24, \mathrm{df}=47$, $1, \mathrm{P}=0.14$ ). Thus, the second null hypothesis, scaffolding instruction has no significant effect on Jordanian tenth-grade EFL students' writing performance on the sub-skills of focus, development, organization, conventions and word choice (at $\alpha \leq 0.05$ ) is rejected for all the sub-skills and accepted for the sub-skill of development. 
8. Discussion, conclusion and recommendations

The first and the second hypotheses assumed no significant effect (at $\alpha \leq 0.05$ ) for scaffolding instruction on both the participants' overall performance and their performance on the sub-skills of focus, development, organization, conventions and word choice. The results showed that students' overall writing performance in the scaffolding instruction group was better than their counterparts in the control group. Statistically significant differences were also found in the students' performance on the sub-skills of focus, organization, conventions and word choice in favor of the scaffolding instruction group. However, no statistically significant differences were found on the sub-skill of development.

The reason for the superior writing performance of the experimental group may probably be attributed to the students' opportunities to share their ideas with the rest of the group during writing and, thus, to function as scaffold for each other. This was made possible through sharing each other's knowledge in the various sub-skills. On the other hand, students in the control group tended to work individually, probably because they were accustomed to this learning style as opposed to collaboration or group work.

In retrospect, the researchers believe that this study had two major fortes. First, by providing appropriate scaffolding instruction, students were able to concentrate on the language, structure and content needed to produce their essays. Second, by using scaffolding instruction, students were able to build links between their beliefs and prior knowledge on one hand, and the topic they were addressing, on the other. This way, these students are believed to have reduced their collective language load as they collaborated to produce their essays.

The results of this study are in line with the general conclusion that scaffolding instruction may enhance writing performance (e.g., Barnard \& Campbell, 2005; Gibbons, 2002; Harris, 1992). Harris (1992), for example, claims that scaffolding instruction promotes students' interaction and moves the student from their traditional role of passive recipients of knowledge from an authority to active involvement in the writing process. 
The interaction among students is also believed to have increased their awareness of the various angles of composition. So, in writing collaboratively, individual students took responsibility for different parts of the text, and, thus, a collective obligation for the final product ensued.

To sum up, the current study supports the sociocultural perspective on language learning, which sees collaborative interactions as a significant source of learning. More importantly, it adds to previous attempts to establish the significance of sociocultural scaffolding and the ZPD from expert/novice relationship to collaborative relationship.

\section{References}

Abu Jaleel, A. (2001). An Investigation of Strategies of Teaching Writing for Ninth and Tenth-graders in Irbid Schools. Unpublished Master's Thesis, The University of Jordan, Amman, Jordan.

Al-Gomoul, M. (2011). Teaching and Assessing Writing Strategies for Secondary School Students and Investigating Teachers' and Students' Attitudes towards Writing Practice. Kamla-Raj, 3(1), 25-36.

Al-Jarf, R. (2007). Online Instruction and Creative Writing by Saudi EFL Freshman Students, King Saud University, Saudi Arabia. Asian EFL Journal, 22(1), 92-107.

Al-Omari, E. (2004). EFL Instructors' Practices for Writing Assessment in Jordanian Universities. Unpublished Master's Thesis, Yarmouk University, Irbid, Jordan.

Al-Quran, M. (2002). The Class-function Confusion in the Complex Sentence Structure: A Study of EFL Student Composition Errors. DIRASAT: Humanities and Social Sciences, 20(3), 821-835.

Al-Sharah, N. (1988). An Analysis of the Problems of Discourse in the Writing of English Majors at Yarmouk University. Unpublished Master's Thesis, Yarmouk University, Irbid, Jordan.

Bani Younis, R. (1997). Assessing Student's Receptivity to their Instructors' Responses in their Foreign Language Writing at both Public and Private Universities in Jordan. Unpublished Master's Thesis, Yarmouk University, Irbid, Jordan.

Baradaran, A. \& Sarfarazi, B. (2011). The Impact of Scaffolding on the Iranian EFL Learners' English Academic Writing. Australian Journal of Basic and Applied Sciences, 5(12), 2265-2273.

Barnard, R. \& Campbell, L. (2005). Sociocultural Theory and the Teaching of Process Writing: The Scaffolding of Learning in a University Context. The TESOLANZ Journal, 13, 76-88. 
Bodrova, E. (1998). Scaffolding Emergent Writing in the Zone of Proximal Development. Literacy Teaching and Learning Journal. 3(2), 1-18. Retrieved 6 April 2015 from https://readingrecovery.org/images/pdfs/Journals/ LTL/LTL Vol3 No2-998/LTL 3.2-Bodrova-Leong.pdf.

Clark, K. \& Graves, M. (2005). Scaffolding Students' Comprehension of Text. The Reading Teacher, 58(6), 570-580.

Eickholdt, L.A. (2004). Scaffolding in the Writing Workshop. Unpublished Doctoral Dissertation, Georgia State University, U.S.A.

Gibbons, P. (2002). Scaffolding Language, Scaffolding Learning: Teaching Second Language Learners in the Mainstream Classroom. Portsmouth (New Hampshire): Heinemann.

Hannafin, M.J., Land, S. \& Oliver, K. (1999). Open Learning Environments: Foundations, Methods and Models. In C.M. Reigeluth (Ed.), Instructional Design Theories and Models: A New Paradigm of Instructional Theory, 2, 115-140. Mahwah (New Jersey): Erlbaum.

Harris, M. (1992). Collaboration is not Collaboration is not Collaboration: Writing Center Tutorials vs. Peer-Response Groups. Composition and Communication, 43(3), 369-83.

Harrison, R. (2004). The Convergence of Community and Communication Online Communities and Japanese Language Education. Retrieved 22 May 2014 from http://www.lib.kobe-u.ac.jp/repository/00523021.pdf.

Hawari, K. (1996). An Analysis Study of the Evaluation Procedures of Writing Employed by EFL Teachers of the First Secondary Grade in Al-Mafraq District. Unpublished Master's Thesis, Yarmouk University, Irbid, Jordan.

Hayati, M. \& Ziyaeimehr, Z. (2011). A Study on the Effect of Scaffolding through Joint Construction Tasks on the Composition of EFL Learners. Studies in Literature and Language, (2)3, 92-102.

Holton, D. \& Clarke, D. (2006). Scaffolding and Metacognition. International Journal of Mathematical Education in Science and Technology, 37 (2), 127-143.

Hyland, K. (2003). Genre-Based Pedagogies: A Social Response to Process. Journal of Second Language Writing, 12(1), 17-29.

Lantolf, J. (2000). Second Language Learning as a Mediated Process. Language Teaching, 33, 79-96.

Lutz, S., Guthrie, J. \& Davis, M. (2006). Scaffolding for Engagement in Elementary School Reading Instruction. Journal of Education and Research, 100(1), 3-20.

Mitchell, R. \& Myles, F. (2004). Second Language Learning Theories. London: Edward Arnold.

Schwieter, J. (2010). Developing Second Language Writing through Scaffolding in the Zone of Proximal Development: A Magazine Project for an Authentic Audience. Journal of College Teaching \& Learning, (7)10, 31-45. Retrieved 5 
Does Scaffolding-Based Instruction Improve Writing Performance?

April 2015 from

http://legacy.wlu.ca/documents/44815/Developing_second_language_ writing.pdf.

Soles, D. (2005). The Academic Essay- How to Plan, Draft, Write and Revise. Somerset (U.K.): Bishops Lydeard.

Van Lier, L. (1996). Interaction in the Language Curriculum: Awareness, Autonomy, and Authenticity. New York: Longman.

Vygotsky, L. (1978). Mind in Society: The Development of Higher Psychological Processes. Cambridge (Massachusetts): Harvard University Press.

Vygotsky, L. S. 1987. Thinking and Speech (N. Minick, Trans.). In R.W. Rieber \& A.S. Carton (Eds.), The Collected Works of L.S. Vygotsky. Volume 1: Problems of General Psychology (37-285). New York: Plenum Press.

Wang, Y \& Laio, H. C. (2008). The Application of Learning Portfolio Assessment for Students in the Technological and Vocational Education System. Asian EFL Journal, 10(2), 132-154.

Wood, D.J. (1998). How Children Think and Learn. Oxford: Blackwell. 